Johanson, W. G., Pierce, A. K., Sanford, J. P., and Thomas, G. D. (1972). Annals of Internal Medicine, 77, 701.

Johnson, W. D., Kaye, D., and Hook, E. W. (1968). American Review of Respiratory Diseases, $97,1112$.

Lipman, M. O., Coss, J. A., and Boots, R. H. (1946). Fournal of Bacteriology, $51,594$.

Long, D. A. (1947). British Medical fournal, 2, 819.

Louria, D. B., and Kaminski, T. (1962). American Review of Respiratory Diseases, 85, 649 .

McCurdy, R. S., and Neter, E. (1952). Pediatrics, 9, 572.

Meads, M., Rowe, W. P., and Haslam, N. M. (1951). Archives of Internal Medicine, 87, 533.
Ory, E. M., Harris, H. W., Meads, M., Wilcox, C., and Finland, M., (1946). fournal of Laboratory and Clinical Medicine, 31, 409.

Petersdorf, R. G., Curtin, J. A., Hoeprich, P. D., Peeler, R. N., and Bennett, I. L. (1957). New England fournal of Medicine, 257, 1001.

Philp, J. R. (1972). In Clinical Concepts in Infectious Diseases ed. L. E. Cluff and J. E. Johnson, p. 326. Baltimore, Williams and Wilkins.

Pines, A., Raafat, H., Siddiqui, G. M., and Greenfield, J. S. B. (1970) British Medical fournal, $1,663$.

Price, D. J. E., and Sleigh, J. D. (1970). Lancet, 2, 1213.

Stratford, B., Gallus, A. S., Mathiesson, A. M., and Dixson, S. (1968) Lancet, $\mathbf{1}, 68$.

Tillotson, J. R., and Finland, M. (1969). Fournal of Infectious Diseases, 119,

\title{
Radioisotopic Bone Scintigraphy with the Gamma Camera in the Investigation of Prostatic Cancer
}

\author{
R. J. SHEARER, A. R. CONSTABLE, M. GIRLING, W. F. HENDRY, J. D. FERGUSSON
}

British Medical fournal, 1974, 2, 362-365

\section{Summary}

Experience with $x$-rays, strontium-87m scintigraphy, and technetium-99m polyphosphate scintigraphy in the identification of bone metastases in 201 patients with prostatic cancer is reviewed. About $40 \%$ of the patients had demonstrable metastases in bone at the time of first presentation.

Comparative studies of $247 \mathrm{x}$-ray and $87 \mathrm{mSr}$ surveys indicated that $x$-rays failed to detect metastases in $10 \%$

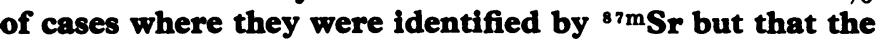
isotopic survey similarly failed to detect radiologically evident deposits in $7 \%$ of cases.

Similar studies comparing '9mTc polyphosphate surveys with $x$-ray scans showed that $x$-rays missed isotopically detected metastases in $12 \%$ of cases, but in only one survey out of 67 did the isotope miss radiologically evident deposits. In a series of 32 patients investigated by both isotopic techniques $"$ 'm Tc polyphosphate did not fail to detect any metastases and identified deposits in one patient in whom they were missed by ${ }^{87 m}$ Sr scintigraphy. About $15 \%$ of both $x$-ray and $87 \mathrm{mSr}$ surveys gave equivocal results, but only $3 \%$ ( 2 out of 67 ) of $9 m$ Tc polyphosphate surveys were equivocal.

We concluded that $\because \mathrm{m}$ Tc polyphosphate bone scintigraphy with the gamma camera was the most reliable of the techniques used for the identification of bone metastases in patients with carcinoma of the prostate. The results of scintigraphy with $87 \mathrm{~m}$ Sr suggested that serial surveys may provide early evidence of hormone resistance in prostatic cancer.

\section{Introduction}

Early and accurate recognition of bone metastases in patients with carcinoma of the prostate is an important part of the

Institute of Urology and St. Peter's Group of Hospitals, London WC2H 8JE

R. J. SHEARER, F.R.C.S., Research Fellow

A. R. CONSTABLE, M.SC., A.nNST.P., Senior Lecturer in Medical Physics M. GIRLING, B.SC., Research Assistant M. GIRLING, B.SC., Research Assistant
W. F. HENDRY, CH.M., F.R.C.S., Senior Lecturer and Honorary Consultant

J. D. FERGUSSON, M.D., F.R.c.s., Consultant Surgeon evaluation of the disease both at the time of initial presentation and during its subsequent course. Extensive change is needed in the texture of bone before metastases become radiologically visible and several reports have emphasized that radioisotopic bone scintigraphy can identify secondary deposits earlier than $x$-rays (Kontturi and Kiviniitty, 1971; Roy et al., 1971; Robinson and Constable, 1973). The principal nucleides used have been fluorine-18, strontium-85, or strontium-87m, but it is recognized that each isotope has drawbacks (O'Mara et al., 1972). Since the introduction of technetium-99m labelled polyphosphate (Subramanian and McAfee, 1971) there has been widespread acceptance of this compound, (Lavender et al., 1972; Redman and Turley, 1973) and clinical comparison of it with other isotopes is needed to evaluate its usefulness and accuracy in the investigation of prostatic carcinoma.

Between 1970 and December 1972 patients attending the prostatic carcinoma unit of the Institute of Urology were investigated by radiological skeletal surveys and by $87 \mathrm{mSr}$ bone scintigraphy. Between January and June $1973^{\circ} \mathrm{om}$ Tc polyphosphate scintigraphy was used as well, and in June 1973 $87 \mathrm{mSr}$ was discontinued. We here present our experience in the use of these various techniques in the recognition of bone secondary deposits.

\section{Patients and Methods}

All patients in this study attended a special unit for the investigation of prostatic cancer. In all cases the diagnosis was established by histological or cystological examination of a prostatic biopsy. A total of 201 patients were investigated by 305 radio-

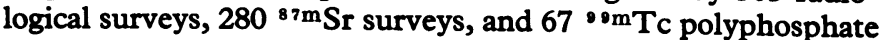
surveys. Radiological skeletal surveys were done by means of $x$-ray examinations of the chest, pelvis, lumbar and dorsal spines, skull (lateral view), femora, and humeri.

Bone scintigraphy was carried out with a Nuclear Enterprises Mk III gamma camera within a few days of the skeletal survey using either ${ }^{87 \mathrm{mSr}}$ or ${ }^{\circ} \mathrm{m} \mathrm{m}$ Tc polyphosphate (Manufactured by Diagnostic Isotopes Ltd. in kit form and supplied by Duphar Petten, Holland). In those cases where both agents were used the ${ }^{87 \mathrm{~m}} \mathrm{Sr}$ generally preceded the ${ }^{\circ 0 \mathrm{~m}} \mathrm{Tc}$ by five days.

The scintigraphic procedure was similar for both agents and the doses given were $1.5-2.0 \mathrm{mCi}{ }^{87} \mathrm{mSr}$ and $8-10 \mathrm{mCi}{ }^{\circ 9 \mathrm{mTc}}$ polyphosphate. The radiation dose to the patient was mainly to the skeleton in both investigations and totalled about 600 mrads for the combined study. The other critical organ was the kidney where the radiation dose can be at least as high as that to bone in the presence of good kidney function and outflow tract obstruction. The doses were given to the patient between 10 a.m. 
and 11 a.m. and scintigraphy began four hours later. The patient first emptied his bladder and the first views taken were those of the pelvis, thus minimizing the bladder contribution to the observed counts though some retention was often observed. Scintigrams were obtained for pelvis, lumbar and dorsal spine, chest, and proximal femora.

The variable indices of the gamma camera display-spot brilliance, camera aperture, and display size-were always set to standard values to achieve some measure of repeatability. A "phantom" exposure to check for uniformity was obtained for each patient. The first scintigram (pelvis) was exposed until 200,000 counts were accumulated and the time for this exposure was noted. The remaining scintigrams were given the same time exposure regardless of counts accumulated. Though the use of the pelvis as the area for the "standardizing" exposure could theoretically result in some under-exposure of other areas of the skeleton because of the variable bladder component in practice this did not occur, and we found no difficulty in interpreting the scintigrams.

The reporting of scintigraphic findings was undertaken jointly by a clinician (R.J.S.) and a physicist (A.R.C.), who inspected the polaroid photographs of the display. A positive diagnosis was made when one or more of the following characteristics was clearly evident: (a) asymmetry of uptake-for example, between right and left sides of the pelvis; $(b)$ non-uniform uptake -for example, intensity variations along the spinal column; (c) isolated hot areas, particularly with $87 \mathrm{mSr}$, in the ribs and shoulders where normal bone can sometimes appear no different from the background tissue.

\section{Results}

The overall findings are shown in table $I$; the results fell into three groups as follows: positive, definite evidence of deposits; suspicious, an abnormal appearance but without any definite areas that could be identified as metastases; and negative, entirely normal appearances. The results in those patients investigated before treatment had been started are shown in table II since it is possible that the high incidence of suspicious results in both the $x$-ray and ${ }^{87 \mathrm{mSr}} \mathrm{Surveys}$ was due to modification of radiological appearances or abnormal metabolic bone activity by hormone therapy. There was, however, no significant change in the distribution of results, and the suspicious survey results remained at about $15 \%$ of both $x$-ray and $87 \mathrm{mSr}$ surveys.

A total of 165 patients were investigated a total of 247 times by simultaneous $x$-ray and $87 \mathrm{mSr}$ surveys and the comparative results are shown in table III. While there was good correlation in most cases-the $x$-ray films and the isotope scan "agreed" in 173 of the 247 investigations-in 24 cases (10\%) where $x$-ray films failed to provide definite evidence of metastases (eight

TABLE I-Overall Results of Radiological and Radioisotopic Surveys in 201 Patients with Carcinoma of the Prostate

\begin{tabular}{|c|c|c|c|c|c|c|c|c|}
\hline & & \multirow{2}{*}{$\begin{array}{c}\text { No. } \\
\text { of } \\
\text { Surveys }\end{array}$} & \multicolumn{2}{|c|}{ Positive } & \multicolumn{2}{|c|}{ Suspicious } & \multicolumn{2}{|c|}{ Negative } \\
\hline & & & No. & $\%$ & No. & $\%$ & No. & $\%$ \\
\hline $\begin{array}{lc}X-R a y & \ldots \\
\text { ormSr } & \ldots \\
\text { om Tc } & \\
\text { polyphosphate }\end{array}$ & $\begin{array}{l}. . \\
. \\
. .\end{array}$ & $\begin{array}{r}305 \\
280 \\
67\end{array}$ & $\begin{array}{r}101 \\
114 \\
33\end{array}$ & $\begin{array}{l}33 \\
41 \\
49\end{array}$ & $\begin{array}{r}36 \\
43 \\
2\end{array}$ & $\begin{array}{r}12 \\
15 \\
3\end{array}$ & $\begin{array}{r}168 \\
123 \\
32\end{array}$ & $\begin{array}{l}55 \\
44 \\
48\end{array}$ \\
\hline
\end{tabular}

TABLB II-Results of Radiological and Radioisotopic Surveys in 129 Patients before Treatment was begun

\begin{tabular}{|c|c|c|c|c|c|c|c|c|}
\hline & & \multirow{2}{*}{$\begin{array}{c}\text { No. } \\
\text { of } \\
\text { Surveys }\end{array}$} & \multicolumn{2}{|c|}{ Positive } & \multicolumn{2}{|c|}{ Suspicious } & \multicolumn{2}{|c|}{ Negative } \\
\hline & & & No. & $\%$ & No. & $\%$ & No. & $\%$ \\
\hline $\begin{array}{lc}X-R a y & \cdots \\
\text { ormSr } & \cdots \\
\text { om Tr } \\
\text { polyphosphate }\end{array}$ & $\begin{array}{l}. . \\
. .\end{array}$ & $\begin{array}{r}129 \\
112 \\
38\end{array}$ & $\begin{array}{l}36 \\
35 \\
16\end{array}$ & $\begin{array}{l}28 \\
31 \\
42\end{array}$ & $\begin{array}{r}21 \\
16 \\
1\end{array}$ & $\begin{array}{c}16 \\
14.5 \\
3\end{array}$ & $\begin{array}{l}72 \\
61 \\
21\end{array}$ & $\begin{array}{l}56 \\
54 \cdot 5 \\
55\end{array}$ \\
\hline
\end{tabular}

TABLE III-Comparison of 247 Radiological and $87 \mathrm{~m}$ Sr Surveys in 165 Patients with Carcinoma of the Prostate. Percentages are given in Parentheses

\begin{tabular}{|c|c|c|c|c|c|c|}
\hline \multirow{2}{*}{\multicolumn{3}{|c|}{$X$-Ray Findings }} & \multicolumn{3}{|c|}{ Results of "mSr Bone Scans } & \multirow{2}{*}{ Total } \\
\hline & & & Positive & Suspicious & Negative & \\
\hline $\begin{array}{l}\text { Positive } \\
\text { Suspicious } \\
\text { Negative }\end{array}$ & $\begin{array}{l}\cdots \\
\cdots\end{array}$ & $\because$. & $\begin{array}{c}71(29) \\
8(3) \\
16(6.5)\end{array}$ & $\begin{array}{c}12(5) \\
9(3.5) \\
19(7 \cdot 5)\end{array}$ & $\begin{array}{c}5(2) \\
14(5 \cdot 5) \\
93(38)\end{array}$ & $\begin{array}{r}88(36) \\
31(12) \\
128(52)\end{array}$ \\
\hline Total $\ldots$ & $\ldots$ & $\ldots$ & $95(39)$ & $40(16)$ & $112(45)$ & $247(100)$ \\
\hline
\end{tabular}

TABLE IV-Comparison of 67 Radiological and $99 \mathrm{~m} T c$ Polyphosphate Surveys in 61 Patients with Carcinoma of the Prostate. Percentages are given in Parenthe-

\begin{tabular}{|c|c|c|c|c|c|c|}
\hline \multicolumn{3}{|c|}{$X$-Ray Findings } & \multicolumn{3}{|c|}{$\begin{array}{c}\text { Results of } " \text { mT } \text { Polyphosphate } \\
\text { Bone Scans }\end{array}$} & \multirow{2}{*}{$\begin{array}{c}\text { Total } \\
26(39) \\
8(12) \\
33(49)\end{array}$} \\
\hline $\begin{array}{l}\text { Positive } \\
\text { Suspicious } \\
\text { Negative }\end{array}$ & & $\begin{array}{l}\cdots \\
\cdots\end{array}$ & $\begin{array}{c}\text { Positive } \\
25 \text { (37) } \\
2 \text { (3) } \\
6(9)\end{array}$ & $\begin{array}{c}\text { Suspicious } \\
0 \\
1(1 \cdot 5) \\
1(1 \cdot 5)\end{array}$ & $\begin{array}{c}\text { Negative } \\
1(1.5) \\
5(7 \cdot 5) \\
26(39)\end{array}$ & \\
\hline Total $\ldots$ & .. & .. & $33(49)$ & $2(3)$ & $32(48)$ & $67(100)$ \\
\hline
\end{tabular}

TABLE v-Comparison of $32{ }^{87 \mathrm{~m} S r}$ and ${ }^{9} 9 \mathrm{~m}$ Tc Polyphosphate Surveys in 32 Patients with Carcinoma of the Prostate. Percentages are given in Parentheses

\begin{tabular}{|c|c|c|c|c|c|c|}
\hline \multirow{2}{*}{\multicolumn{3}{|c|}{ s?mSr Findings }} & \multicolumn{3}{|c|}{ "mTc Polyphosphate Bone Scans } & \multirow{2}{*}{ Total } \\
\hline & & & Positive & Suspicious & Negative & \\
\hline $\begin{array}{l}\text { Positive } \\
\text { Suspicious } \\
\text { Negative }\end{array}$ & $\begin{array}{l}\cdots \\
\cdots\end{array}$ & $\begin{array}{l}\cdots \\
\cdots\end{array}$ & $\begin{array}{c}14(44) \\
1(3) \\
0\end{array}$ & $\begin{array}{l}0 \\
0 \\
2(6)\end{array}$ & $\begin{array}{l}0 \\
2(6) \\
13(41)\end{array}$ & $\begin{array}{c}14(44) \\
3(9) \\
15(47)\end{array}$ \\
\hline Total & .. & .. & $15(47)$ & $2(6)$ & $15(47)$ & $32(100)$ \\
\hline
\end{tabular}

suspicious results, 16 negative results) such evidence was supplied by strontium scintigraphy. There were, however, 17 cases $(7 \%)$ in which the strontium survey did not recognize metastases that were visible on $x$-ray films, and in nine cases (3.5\%) metastases could neither be identified nor ruled out even after both investigations.

Sixty-one patients were investigated by simultaneous $x$-ray and $\theta 9 \mathrm{~m}$ Tc polyphosphate surveys (67 investigations) and the comparative results are shown in table IV. Polyphosphate scintigraphy identified metastases in eight cases $(12 \%)$ not seen on $x$-ray films, and in only one case did the $x$-ray identify deposits missed on the isotopic survey. One patient presented suspicious. appearances to both the $x$-ray and the ${ }^{\circ} \mathrm{mm}$ Tc polyphosphate scan; this was a man with primary carcinoma of both bladder and prostate whose radiological appearances could have been those of either metastases or Paget's disease. The patient with a suspicious result of a polyphosphate survey but whose $x$-ray pictures appeared normal subsequently had a further polyphosphate survey which showed definitely positive results, and he developed back pain related to that area of his spine though his $x$-ray findings remained negative. These results indicated that though $9 \mathrm{~m} \mathrm{Tc}$ polyphosphate was not significantly better than $87 \mathrm{mSr}$ at detecting metastases missed by $x$-rays $(P \simeq 0.9)$ the lower incidence of false negative results using om Tc polyphosphate was probably significant $(P<0.05)$ and there was a significant reduction of equivocal results $(P<0.01)$.

Thirty-two patients were studied by simultaneous ${ }^{87 m} \mathrm{Sr}$ and - m Tc polyphosphate surveys and the comparative results are shown in table V. In no case did ${ }^{\circ \mathrm{m}} \mathrm{Tc}$ polyphosphate fail to confirm metastases identified by the strontium survey, and in one case a suspicious ${ }^{87 \mathrm{~m}} \mathrm{Sr}$ survey finding was definitely positive on polyphosphate scintigraphy. The two suspicious polyphosphate results discussed above were both negative on ${ }^{87 m} \mathrm{Sr}$ survey. A comparison of $x$-ray survey results with those of the two methods of isotopic scintigraphy in the 32 patients is shown in table VI. 
TABLE VI-Comparison of 32 Radiological Surveys with ${ }^{87 m}$ Sr and $99 \mathrm{~m}$ Tc Polyphosphate Surveys in 32 Patients with Carcinoma of the Prostate

\begin{tabular}{|c|c|c|c|c|c|c|c|c|c|c|c|}
\hline \multirow{2}{*}{\multicolumn{6}{|c|}{ No. (\%) $X$-Ray Findings: }} & \multirow{2}{*}{$\frac{\text { No. }(\%)}{\text { Positive }}$} & \multirow{2}{*}{$\frac{{ }^{87 m} \mathrm{mr} \text { Bone Sc }}{\text { Suspicious }}$} & \multirow{2}{*}{$\frac{\text { Findings: }}{\text { Negative }}$} & \multicolumn{3}{|c|}{ No. $(\%)^{\prime m} \mathrm{Tc}$ Polyphosphate Bone Scan Findings: } \\
\hline & & & & & & & & & Positive & Suspicious & Negative \\
\hline $\begin{array}{l}\text { Positive } \\
\text { Suspicious } \\
\text { Negative }\end{array}$ & $\begin{array}{l}\cdots \\
\cdots\end{array}$ & $\begin{array}{l}\cdots \\
\cdots\end{array}$ & $\begin{array}{l}\ldots \\
\cdots\end{array}$ & $\begin{array}{l}\ldots \\
\cdots\end{array}$ & $\begin{array}{l}13(40.5) \\
3(9 \cdot 5) \\
16(50)\end{array}$ & $\begin{array}{l}13(40 \cdot 5) \\
0 \\
1(3)\end{array}$ & $\begin{array}{l}0 \\
0 \\
3(9 \cdot 5)\end{array}$ & $\begin{array}{c}0 \\
3(9 \cdot 5) \\
12(37 \cdot 5)\end{array}$ & $\begin{array}{l}13(40.5) \\
0 \\
2(6.5)\end{array}$ & $\begin{array}{l}0 \\
1(3) \\
1(3)\end{array}$ & $\begin{array}{l}0 \\
2(6 \cdot 5) \\
13(40 \cdot 5)\end{array}$ \\
\hline
\end{tabular}

To find out whether reduction in bone activity, as shown in the survey after a period of hormone therapy of at least three months, can be used as an objective indicator of prognosis or response to treatment we studied further 30 patients investigated by serial $87 \mathrm{mSr}$ surveys in whom there was an initial positive finding. In seven the second survey gave a negative result, in 22 the result remained positive, and in one patient the second survey gave a suspicious result. Of the 22 patients with persistently positive results 10 complained of bone pain at the time of the first investigation, and in six hormone treatment failed to relieve the pain completely. Of the seven patients whose findings became negative two had bone pain at the time of the first investigation, which was completely relieved in both cases by hormone therapy. Because of the small numbers, these differences were not statistically significant.

Of the 22 patients with persistently positive survey results $17(77 \%)$ had raised serum tartrate labile acid phosphatase levels at the time of the first survey (mean $27.4 \mathrm{~K}$.A. units $/ 100 \mathrm{ml}$, range $1 \cdot 4-317.0 \mathrm{~K}$.A. units $/ 100 \mathrm{ml}$ ), and in only four did the acid phosphatase fall to normal by the time of the second investigation. In the remaining 13 the mean level at the second investigation was $37.4 \mathrm{~K}$.A. units $/ 100 \mathrm{ml}$ (range $1 \cdot 0-280 \mathrm{~K}$.A. units $/ 100 \mathrm{ml}$ ). In contrast four of the seven patients whose results became negative had initially raised serum acid phosphatase (mean $7.8 \mathrm{~K} . \mathrm{A}$. units $/ 100 \mathrm{ml}$, range $2 \cdot 4-11.5 \mathrm{~K}$.A. units/ $100 \mathrm{ml}$ ), and in all four the acid phosphatase subsequently became normal (mean $0.5 \mathrm{~K}$.A. units $/ 100 \mathrm{ml}$, range $0 \cdot 3-0.7$ K.A. units $/ 100 \mathrm{ml}$ ). There was, however, no statistically significant alteration in the acid phosphatase levels in either group.

All seven of the patients with negative results of second surveys were alive and had no evidence of activity of their disease after at least two years, whereas 12 of the 22 with persistently positive surveys died of cancer, only one patient surviving more than 18 months after first presentation. Of the remaining 10 patients, three were alive but had symptoms indicating activity of their tumours, six $(27 \%)$ became symptom free, and one patient died of left ventricular failure three months after starting hormone therapy; at that time he was complaining of severe bone pain and his serum acid phosphatase level was rising rapidly. Patients with prostatic carcinoma whose bone scintigraphy findings become negative after at least three months hormone therapy are therefore more likely to survive at least two years than those whose scintigraphy findings remain positive ( $P$ $<0.01)$.

\section{Discussion}

The physical characteristics of ${ }^{\prime 9 m} \mathrm{Tc}$ make it very suitable for scanning with the gamma camera; its photon energy of $140 \mathrm{keV}$ is suitable for detection with the $12.5 \mathrm{~mm}$ sodium iodide crystal. Because of the larger doses of ${ }^{\circ} \mathrm{m} \mathrm{Tc}$ polyphosphate given, photographic exposure time was less than with $87 \mathrm{~m} \mathrm{Sr}$, and all patients who had both $99 \mathrm{~m} \mathrm{Tc}$ polyphosphate and $87 \mathrm{mSr}$ scans preferred the polyphosphate since it entailed less time lying immobile under the gamma camera. All users of $90 \mathrm{~m} T \mathrm{~T}$ polyphosphate have been impressed by the photographic quality of the views obtained, and our experience is no exception, but critical evaluation of any new technique in the light of previous experience is essential before it is accepted for routine clinical use. Our experience over three years led us to conclude that
${ }^{87} \mathrm{mSr}$ bone scintigraphy was a reliable method of identifying metastatic prostatic carcinoma. Nevertheless in a significant proportion of cases it failed to detect radiologically visible deposits, and in a further group of patients no definite conclusion could be reached as to the presence or absence of metastases. No single explanation can be advanced to account for these difficulties. It is, however, possibly significant that 12 of the 17 false negative or equivocal $87 \mathrm{mSr}$ scintigrams were in patients already undergoing hormone treatment at the time of investigation. Possibly therapy had modified the metabolism of the abnormal bone areas so as to render differentiation between metastases and normal bone less certain, a contention supported by changes in the serum phosphatases that we have seen in these patients. The remaining five false negative $87 \mathrm{mSr}$ scintigrams formed no recognizable pattern; in particular there was no one anatomical site at which scintigraphy was especially inefficient.

A uniformly high uptake throughout the skeleton was considered of dubious diagnostic value and could have indicated either widespread secondary deposits or unusually high uptake in normal bone. The one patient with positive $x$-ray results but negative ${ }^{9} 9 \mathrm{~m} \mathrm{Tc}$ polyphosphate survey results fell into this group though a subsequent survey in this patient gave definitely positive results.

Before discarding strontium in favour of $9 \mathrm{~m} \mathrm{~m}$ T polyphosphate we were concerned not only to see whether we could improve our identification of deposits but also to assure ourselves that we were not missing metastases with ${ }^{\circ} \mathrm{mm} \mathrm{Tc}$ polyphosphate that we could detect with ${ }^{87 \mathrm{~m} S r}$. Our results indicated that ${ }^{9} \mathrm{~m}$ Tc polyphosphate does indeed help us to recognize the metastases more easily and earlier than either ${ }^{87 \mathrm{mSr}}$ or $x$-rays and misses less than either. Its greatest value, however, probably lies in the fact that because of the better quality of photographs obtained the uncertain area of suspicious scans is reduced.

Our clinical experience with prostatic cancer has led us to the conclusion that though most cases are responsive to hormone therapy a proportion of patients (about 15\%) do not respond to oestrogens or orchidectomy. Because of the protean manifestations and slow clinical course of carcinoma of the prostate identification of this group is difficult, and by the time it becomes clinically apparent that the tumour is hormone resistant it is usually too late to provide anything other than brief palliation by other treatment. The results obtained in the small group of patients with metastatic disease studied by serial $87 \mathrm{mSr}$ surveys suggest that failure of a positive finding on a survey to revert to normal after a period of adequate hormone therapy may be an early indication that the tumour is hormone resistant and should perhaps be treated by alternative means. The better definition of metastases obtained with $\circ \mathrm{mT}$ Tc polyphosphate surveys suggests that this may provide a more precise method of identifying the hormone-resistant tumour, and possibly the first indication of escape from control of a previously hormone-sensitive tumour may be given by the polyphosphate survey. We have therefore instituted further investigation of this problem.

\section{CONCLUSIONS}

Bone scintigraphy with the gamma camera after injection of ${ }^{87 \mathrm{~m} S r}$ provides earlier identification of metastases than $x$-ray surveys but is not sufficiently reliable, because of false negatives 
and a high incidence of uncertain scan findings, to be used as the only method of search for secondary deposits. The greater accuracy of $\cdot 9 \mathrm{~m}$ Tc polyphosphate makes it more suitable as the principle means of search though in one patient of the 61 investigated with this isotope we were unable to identify metastases which were clinically and radiologically evident. Care also needs to be used in the interpretction of positive results since an isotopic "hot spot" is a non-specific indicator of abnormal metabolic bone activity and can therefore be produced by any metabolically active lesion, such as are seen, for example, in Paget's disease. We do not envisage that polyphosphate scintigraphy will completely replace $x$-ray examination in the identification of bone metastases, but we do feel that it should be used as the principle "search weapon" both in the initial assessment of the patient with prostatic cancer and in the continuing management of the disease.

We thank Drs. J. J. Stevenson and T. Sherwood, consultant radiologists at St. Peter's Hospitals, who reviewed and reported on the $x$-ray pictures of the patients in our study, and we are indebted to Dr. Sherwood for the first suggestion for the polyphosphate study. We thank also Mr. J. P. Williams, subdean, Institute of Urology, Mr. J. C. Park, consultant urologist at Greenwich District Hospital, and the consultant urologists of the St. Peter's Hospitals who referred many of their patients to us. This work was supported by the St. Peter's Research Trust.

\section{References}

Kontturi, M., and Kiviniitty, K. (1971). Scandinavian Gournal of Urology and Nephrology, $5,210$.

Lavender, J. P., Merrick, M. V., Burn, J. I., and Witt, J. (1972). Lancet,

O'Mara, R. E., and Subramanian, G. (1972). Seminars in Nuclear Medicine, $2,38$.

Redman, J. F., and Turley, J. T. (1973). Urology, 1, 218.

Robinson, M. R. G., and Constable, A. R. (1973). British fournal of Urology, 45, 173 .

Roy, R. R., Nathan, B. E., Beales, J. S. M., and Chisholm, G. D. (1971). British fournal of Urology, 43, 58.

Subramanian, G., and McAfee, J. G. (1971). Radiology, 99, 192.

\section{MEDICAL MEMORANDA}

\section{Development of Heart Valve Lesions during Methysergide Therapy}

\section{R. A. MISCH}

British Medical fournal, 1974, 2, 365-366

Methysergide is a pharmacological antagonist of serotonin and is used mainly for the prophylaxis of migraine. Unwanted side effects on normal therapeutic doses occur in $10-15 \%$ of cases and retroperitoneal fibrosis is likely to occur in about $1 \%$ of all cases treated continuously for more than a year (Neleman, 1972). The fibrosclerotic side effects causing retroperitoneal and pleuropulmonary fibrosis have been well documented (Graham, 1964, 1967). During 1968-70 some 50,000 E.C. 10 prescriptions of methysergide were issued in England and Wales, and during that time four cases each of peritoneal fibrosis and pleural fibrosis were reported to the Adverse Reaction Register (Committee on Safety of Medicines, personal communication). The yearly number of E.C. 10 prescriptions in England and Wales fell from 23,000 in 1968 to 800 by 1972, probably due to the recognition of these side effects. Valvular insufficiences due to methysergide appear to be less widely known (Graham, 1967). This paper describes a case involving the tricuspid and mitral valves.

\section{Case Report}

A 48-year-old aircraft mechanic with hemiplegic migraine had been taking methysergide $2 \mathrm{mg}$ twice daily for four years. This was the only drug able to control his attacks though it did not affect his gradually progressive dementia and extrapyramidal disorder. Investigation showed no retroperitoneal fibrosis, no cardiac symptoms and no murmurs. Blood pressure was 140/80 $\mathrm{mm} \mathrm{Hg}$ and the E.C.G.

Lister Hospital, Stevenage, Herts

K. A. MISCH, F.R.C.PATH., Consultant Pathologist was normal. There was no history of rheumatic fever. A 24-hour urine sample contained less than $10 \mathrm{mg}$ 5-hydroxyindoleacetic acid. He became bedridden as a result of dementia and extrapyramidal ataxia and died with an intercurrent pulmonary infection.

At necropsy death was found to have been due to lobar pneumonia. The brain showed areas of cystic degeneration of white matter. The heart was normal externally and weighed $370 \mathrm{~g}$. The mitral valve showed mild stenosis, admitting only two fingertips $(2 \mathrm{~cm}$ diameter) and feeling stiffer than normal. There was a strikingly uniform, glistening white thickening of the chordae tendineae with some fusion which extended on to the ventricular aspect of the valve leaves, producing fan-shaped ridges. Slight diffuse thickening was present on adjacent parts of the cusp surfaces (fig. 1). The anterior and septal cusps of the tricuspid valve were similarly but less severely affected (fig. 2). The aortic and pulmonary valves were normal. The only other endocardial lesion was a 5-mm white fibrous thickening on the septum below the aortic valve resembling a "jet" lesion caused by turbulence. The myocardium and pericardium were normal. The abdominal organs were normal and there was no obvious retroperitoneal fibrosis.

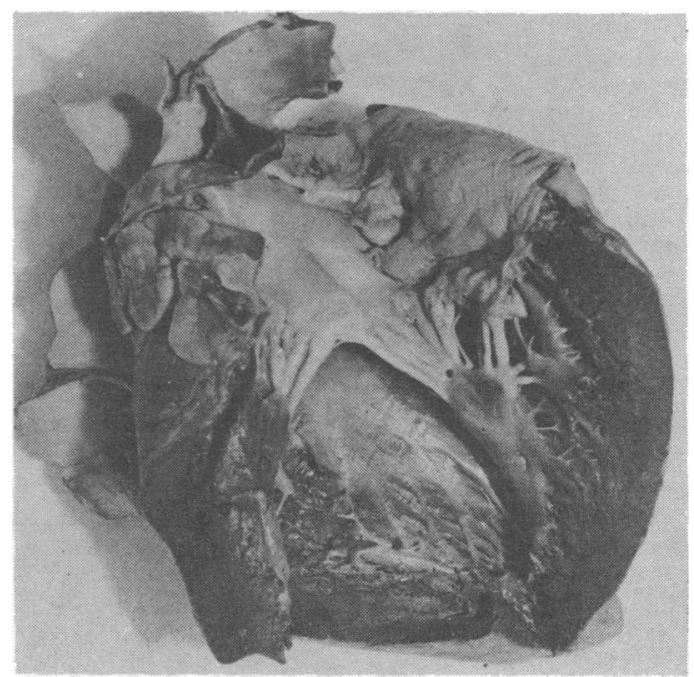

FIG. 1-Mitral valve after four years of methysergide therapy. Chordae tendineae are covered with smooth white fibrous tissue. 